\title{
Mixing physical habitat and streamflow time series analysis
}

\author{
Robert T. Milhous ${ }^{(1)}$ \\ Corresponding Author: Robert Milhous, robert_milhous@usgs.gov
}

\begin{abstract}
Four observations from two case studies are presented: physical habitat analysis of the Virgin River in southwestern Utah and upper Animas Basin in southwestern Colorado. The Virgin River is usually considered a sand bed river. Cross-sectional measurements, made at three streamflows, show there was considerable change in the channel between the times of the three sets of measurements. First observation: it is important to keep the three sets of data as individual data sets. Second observation: the channel index is not fixed in a river with a moveable-bed and changes affect understanding of the aquatic system. The Animas River has a wide range of streamflows and high metals toxicity. Both winter and spring discharges may limit trout populations. Third observation: (from Animas River) habitat time series analysis should be done with a model that specifically links physical habitat relations and streamflows. Fourth observation: annual time series of habitat suitability considering metals toxicity can be generated. Considering the third and fourth observation together leads to the secondary observation that the hydraulic and stream flow conditions that favor one species may not be as good for the species favored by the water quality conditions.
\end{abstract}

Key words. - time series analysis, physical habitat modeling, Animas River, Virgin River

\section{INTRODUCTION}

Four "observations" from two case studies of physical habitat analysis are presented in this paper. The central theme is that considerable knowledge about the aquatic environment is gained by the development of an understanding of how the physical habitat changes with time (time series simulation). The two case studies are the Virgin River in southwestern
Utah, and the Animas River in southwestern Colorado. The Virgin River case study illustrates two of the four observations: 1) the importance of separate analysis of data sets obtained at different times when a river channel changes with time, and 2) that there can be important changes in the substrate with time. There are two additional observations from the Animas River case study. The first is that time series analysis can be used

(1) Fort Collins Science Centre, US Geological Survey. 2150 Centre Avenue, Building C. Fort Collins, Colorado 80526. email: robert_milhous@usgs.gov. 
to investigate the importance of the annual extremes of streamflows (spring runoff - high streamflow, and winter base flow - low streamflow) to the quality of the physical habitat. The second observation is that a time series of habitat suitability can be developed that includes the impact of metals concentrations on the overall suitability.

This paper illustrates the process of developing habitat time series by presenting a series of graphs. The goal is to show how to develop time series of importance to the analysis of physical habitat for aquatic animals. The paper does not justify any of the analytical paths illustrated in the paper. The paper is a way station' in the process of attempting to improve environmental flow analysis with an end goal of making an improvement to techniques for linking streamflow, physical habitat simulation, and a habitat quality index as represented by the Index of Biotic Integrity (Karr, 1991).

Assumptions made in writing this paper are that the reader has 1) a working knowledge of the Physical Habitat Simulation System (PHABSIM), see Milhous et al. (1989) for details; and 2) at least some knowledge of habitat time series analysis within the context of the Instream Flow Incremental Method (IFIM), see Milhous et al. (1990) for details. The four 'observations' are independent and are not linked except in the discussion. The reader should obtain some insight into how to improve the use of time series analysis using habitat simulation from each of the four observations.

\section{VIRGIN RIVER CASE STUDY}

The Virgin River is a mostly sand bed river. The study area is located in Washington County Utah and in adjacent Arizona and Nevada. Most of the study reaches are not stable in that the channel changes reasonably frequently. There are some stable reaches in the upper reaches of the river. Information for only one reach of the river is presented in this paper. The reach is in Little Round Valley near Hurricane, Utah.

Observation 1. In a moveable channel it is important to keep channel data sets separate for a time series analysis.

The physical habitat versus discharge relations for desert suckers larger than $90 \mathrm{~mm}$ in the Little Round Valley reach are presented in Figure 1 . The relations were calculated using three different measured data sets and various programs in the Physical Habitat Simulation System (PHABSIM). The programs are described in Milhous et al. (1989). In this paper monthly values of the streamflows on the Virgin River near Hurricane are being used in the time series analysis. The maximum monthly discharge during the period of record was $1657 \mathrm{cfs}(46.9 \mathrm{cms})$. The physical habitat relations were developed using discharges between 12 and 1000 cfs (0.34 and $28.3 \mathrm{cms}$ ) 


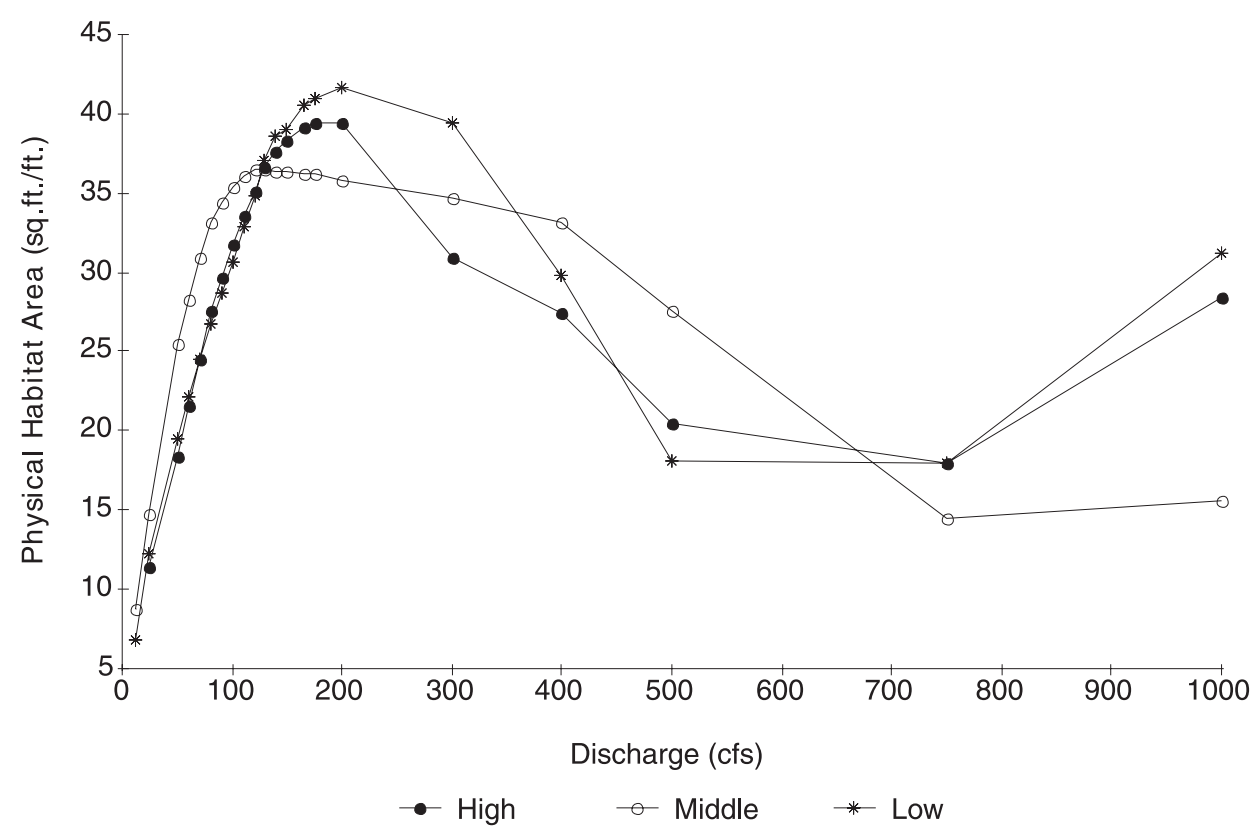

Fig. 1. - Physical habitat versus discharge relations for desert sucker (Catostomus clarki) in the Virgin River at Little Round Valley, Utah. The three sets of measurements used to calculate the relations were made on 10 June 93 (high flow data set $-387 \mathrm{cfs}$ ), 23 July 93 (low flow data set $-71 \mathrm{cfs}$ ), and 02 March 94 (middle flow data set $-278 \mathrm{cfs}$ ). (100 cfs $=2.83 \mathrm{cms}$ and $10 \mathrm{sq}$. ft. $/ \mathrm{ft}$. $=3.048 \mathrm{sq}$. $\mathrm{m} . / \mathrm{m}$.)

and linear interpolation used for the $3 \%$ of monthly discharges larger than $1000 \mathrm{cfs}$. It was assumed the physical habitat at a discharge of zero was also zero.

The relations in Figure 1 are composites of two relations calculated using different sets of velocities and cross-sectional measurements to calibrate the PHABSIM hydraulic models. There is a significant concern that the measured velocities will not result in a good relation for discharges up to $1000 \mathrm{cfs}(28.3 \mathrm{cms})$. A procedure for dealing with this concern is to simulate the relations using hydraulic models in PHABSIM calibrated to depth only for the higher discharges. This was done and the weights used to merge the two relations (calibrated to velocity, calibrated to depth only) for the three sets of data (Table 1). For discharges less than the calibration discharge the velocity calibrated results were always used; for the two highest discharges (750 and $1000 \mathrm{cfs} /$ 21.2 and $28.3 \mathrm{cms}$ ) the depth only calibration was used; and for intermediate discharges, judgment was used in selecting the weights. An example of how the relations are combined into a single relation is shown in Figure 2 for the middle discharge data set. The equation used to combine a 
Table 1. - Weights shown in the table are the weights on the physical habitat relation calculated using models in PHABSIM calibrated to measured velocities and depths. The weight on the physical habitat calibrated to variation in depth only is one minus the weight shown in the table. The dates and measured discharge for the three (high, low, and middle) measured data sets. (100 cfs = $2.83 \mathrm{cms})$

\begin{tabular}{|c|c|c|c|c|}
\hline & & $\begin{array}{l}\text { High } \\
10 / 06 / 93\end{array}$ & $\begin{array}{l}\text { Low } \\
23 / 07 / 93\end{array}$ & $\begin{array}{l}\text { Middle } \\
2 / 03 / 94\end{array}$ \\
\hline Discharge (cfs) & Discharge (cms) & $387 \mathrm{cfs}$ & $71 \mathrm{cfs}$ & $278 \mathrm{cfs}$ \\
\hline 12 & 0.34 & 1 & 1 & 1 \\
\hline 25 & 0.71 & 1 & 1 & 1 \\
\hline 50 & 1.42 & 1 & 1 & 1 \\
\hline 60 & 1.70 & 1 & 1 & 1 \\
\hline 70 & 1.98 & 1 & 1 & 1 \\
\hline 80 & 2.27 & 1 & 1 & 1 \\
\hline 90 & 2.55 & 1 & 1 & 1 \\
\hline 100 & 2.83 & 1 & 1 & 1 \\
\hline 110 & 3.11 & 1 & 0.67 & 1 \\
\hline 120 & 3.40 & 1 & 0.33 & 1 \\
\hline 130 & 3.68 & 1 & 0 & 1 \\
\hline 140 & 3.96 & 1 & 0 & 1 \\
\hline 150 & 4.25 & 1 & 0 & 1 \\
\hline 165 & 4.67 & 1 & 0 & 1 \\
\hline 175 & 4.96 & 1 & 0 & 1 \\
\hline 200 & 5.66 & 1 & 0 & 1 \\
\hline 300 & 8.49 & 1 & 0 & 0.67 \\
\hline 400 & 11.33 & 0.67 & 0 & 0.33 \\
\hline 500 & 14.16 & 0.33 & 0 & 0 \\
\hline 750 & 21.24 & 0 & 0 & 0 \\
\hline 1000 & 28.32 & 0 & 0 & 0 \\
\hline
\end{tabular}

relation calculated using a velocity and depth calibrated model with a relation calculated using a model with only depth calibration is:

$$
\begin{aligned}
& \operatorname{HAC}(i)= \\
& {\left[\operatorname{HAV}(i)^{*} w(i)\right]+[\operatorname{HAD}(i) *(1-w(i))]}
\end{aligned}
$$

where $\mathrm{HAV}(\mathrm{i})$ is the habitat calculated using the velocity calibration, $\operatorname{HAD}(\mathrm{i})$ the habitat calculated with depth cali- bration only, and $\mathrm{HAC}(\mathrm{i})$ is the composite (or weighted) habitat. The weight on the habitat calculated using the velocity-calibrated model is $w(i)$. Both $w(i)$ and $(1-w(i))$ are given in Table 1.

The first approach to handling the three different relations in Figure 1 would be to assign a range of discharges to each of the three sets 


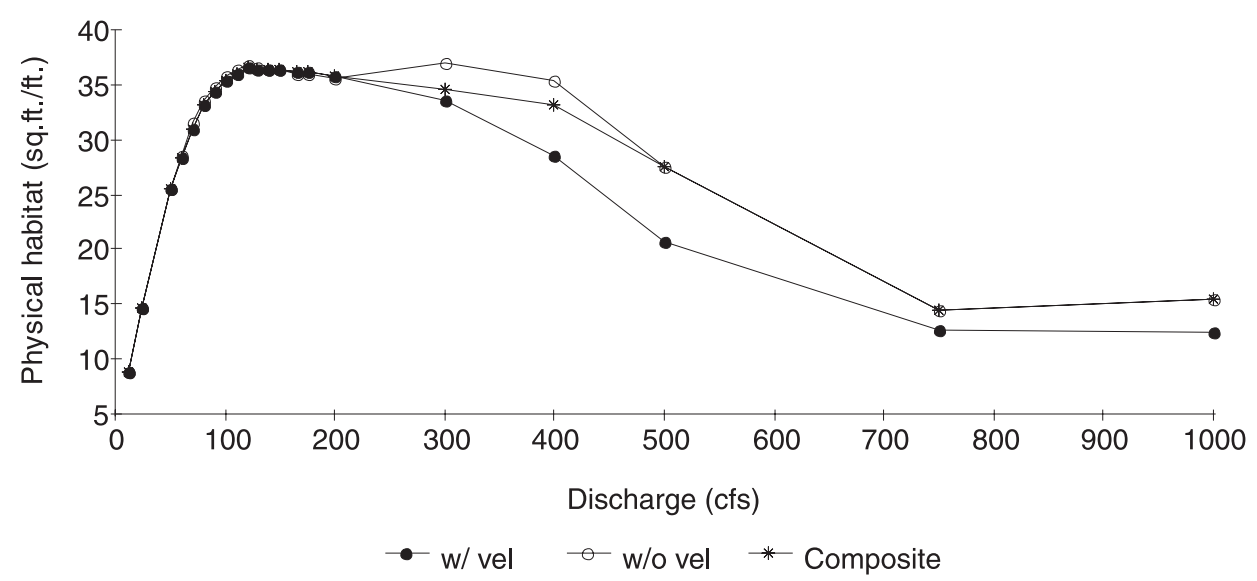

Fig. 2. - The physical habitat versus discharge relations for Desert Suckers larger than $90 \mathrm{~mm}$ in the Virgin River at Little Round Valley, Utah based on the middle set of discharge measurements. $(100 \mathrm{cfs}=2.83 \mathrm{cms}$ and $10 \mathrm{sq} . \mathrm{ft} . / \mathrm{ft}$. $=3.048 \mathrm{sq} . \mathrm{m} . / \mathrm{m}$. $)$

based on the discharges. But before that is done, the channel morphology data should be reviewed. This is accomplished by comparing cross sections, and the longitudinal profiles, for the three different data sets. The longitudinal profiles for the three data sets available for the Little Round Valley reach are presented in Figure 3. The working assumption behind the idea of using segments of each relation is that the channel deepens as the discharge increase and fills as the flow decreases; in addition it is assumed that the pattern repeats with each successive pattern of streamflows. Note that in Figure 3 this assumed pattern does not occur because the thalweg of the middle discharge (Mid $Q$ ) is below both the low flow and high flow thalweg. For the assumption of scour and fill in a predictable relation between discharge and thalweg depth to be true, the middle discharge thalweg should be between the high and low discharge thalwegs. The high discharge thalweg profile is mostly above the other two thalweg profiles (except for the cross section at about 600 feet (182.9 meters)) the low discharge data set smoothed the thalweg profile by filling the hole at about 600 feet and removing the 'hump' at about 180 feet.

The daily streamflows in the Virgin River at Hurricane during the period of the field measurements and just prior to the first measurement are presented in Figure 4. The smoothing of the profile probably occurred because the river had sufficient competence to move the substrate material (mostly sand) and continued to move the sand in the river without much sand being delivered to the main channel. Prior to the high discharge set of measurements the river almost 


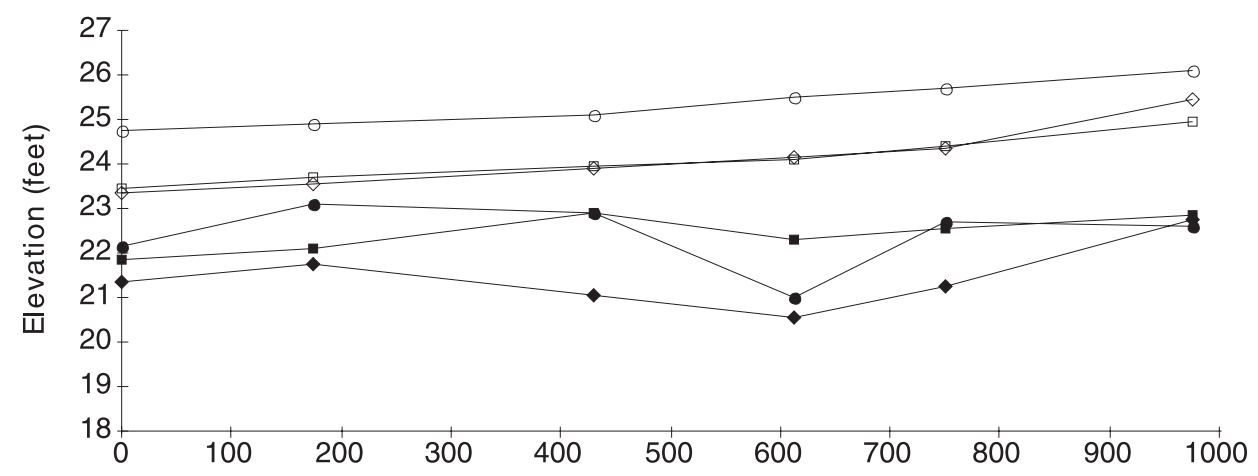

Accum. Reach Length (feet)

$\begin{array}{lll}- \text { High Q } & \rightarrow \text { High Q } & - \text { Low } Q \\ - \text { Low } Q & \rightarrow \text { Mid Q } & \rightarrow \text { Mid Q }\end{array}$

Fig. 3. - Longitudinal Profile of the Little Round Valley Reach of the Virgin River, Colorado for three sets of cross-sectional measurements. ( $1 \mathrm{foot}=0.3048$ meters). Bottom three lines are the ground profiles, the upper three are the surface water profiles.

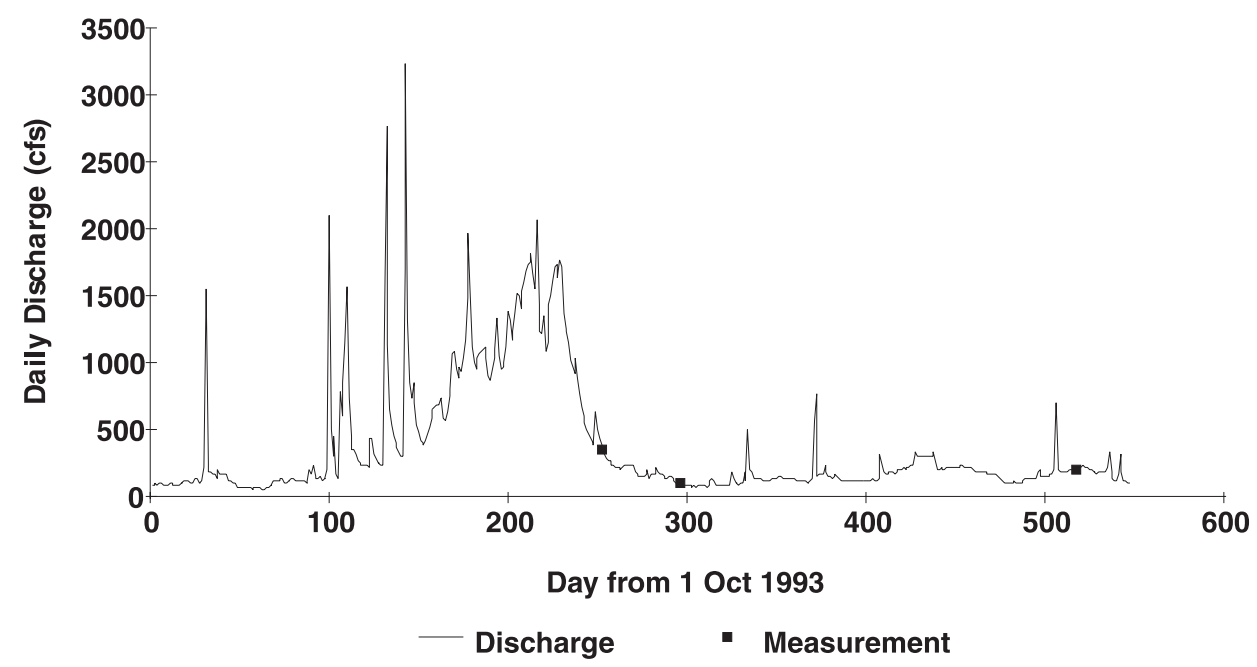

Fig. 4. - Daily discharges in the Virgin River near Hurricane, Utah from 1 October 1992 thru 31 March 1994 (547 days). (100 cfs $=2.83 \mathrm{cms}$ )

certainly received large quantities of sediment from the tributaries. In Figure 3 the profile for the middle set of discharges shows the river has con- tinued to remove sediment along the whole of the reach between the end of July 1993 and early March 1994. 


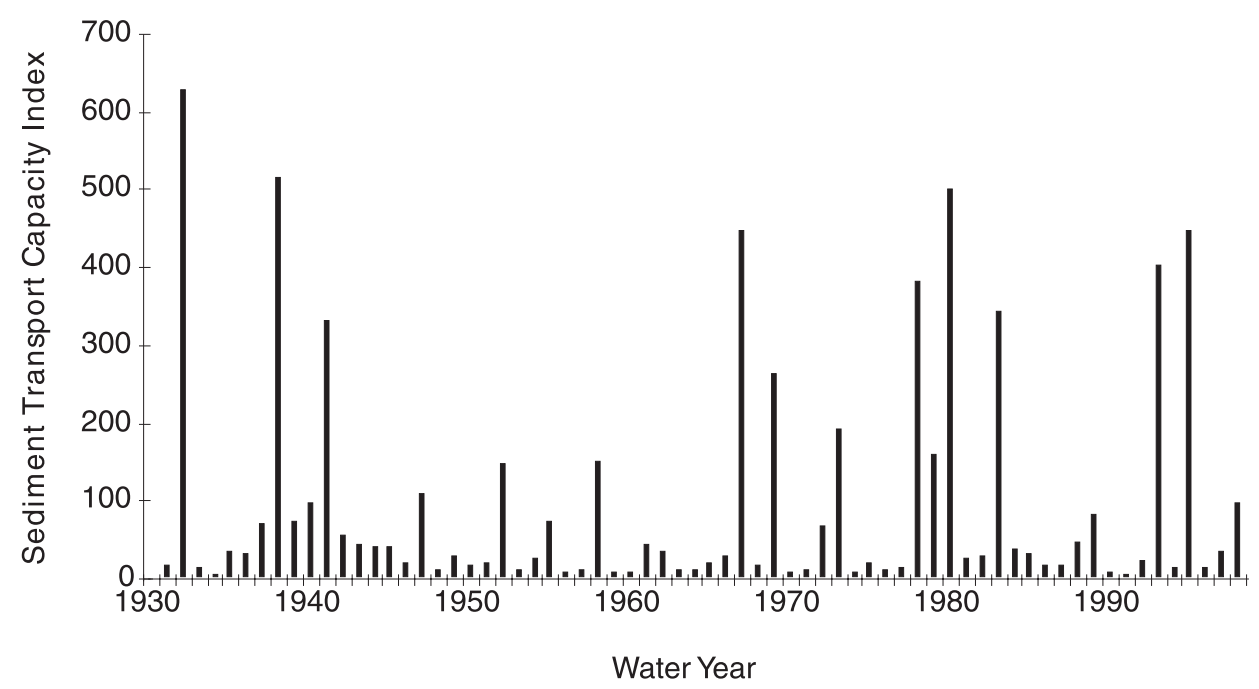

Fig. 5. - Sediment transport capacity index for the Littlefield, Arizona gage (Virgin River at Littlefield, AZ). A major dam-break flood occurred in 1989; if the STCI gives us information on the yield of sediment to the river then 1993 followed a period with small yield to the river.

An index of the ability of a river to transport sediment has been developed (Milhous, 1995). This index (Sediment Transport Capacity Index - STCI) was calculated for a gage with a long record further downstream than the Hurricane gage. The annual values of the STCl are presented in Figure 5. The longer record was used in order to show how the STCI varies over as long a period as possible. A dam-break flood in 1989 probably modified the channel and the 1993 events could have caused a return to the old - except other sites on the Virgin River above the failure had a similar change.

The change in the channel is not a simple relation between the discharge and the channel shape (meaning the scour/fill of the cross section is not related only to discharge - filling as the flows decrease, scouring as the flow increases) but the channel shape is related to the past history of the streamflows and the sediment yield to the stream from the tributary watershed. The high flow channel probably represents the channel following major storms, and the middle set a common condition after the sediment (sand) has had time to move through the system. The low flow data set may represent the channel following the more common storms with reasonably high discharges but not storms (as in 1993) that may have move significant amounts of sand from the watershed to the channel. The change in the channel in 1993 was certainly related to the storms that occurred the winter before. 


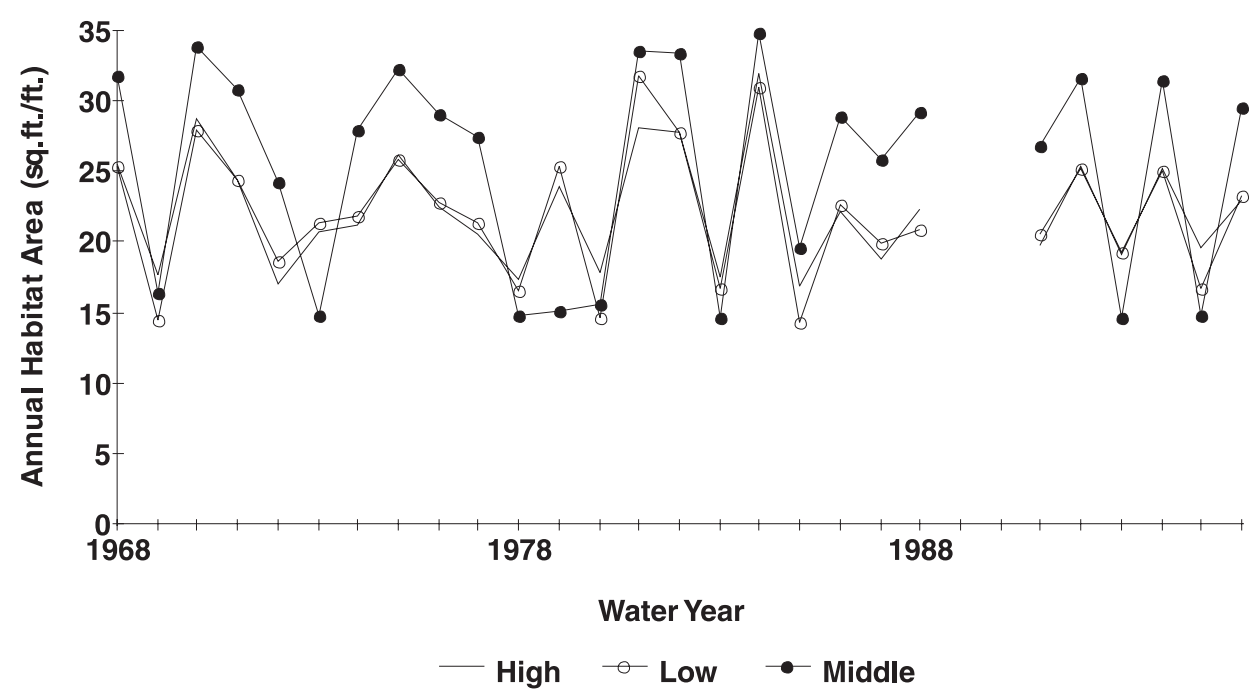

Fig. 6. - Three time series of the monthly habitats for desert suckers larger then $90 \mathrm{~mm}$ for the Little Round Valley reach of the Virgin River. Streamflows used in the simulation were the monthly discharges at the Hurricane gage on the Virgin River. The habitat relations used were calculated using the three (high, low middle) different data sets. (10 sq. ft./ft. $=3.048 \mathrm{sq} . \mathrm{m} . / \mathrm{m}$.)

The time series of the three physical habitat versus discharge relations are given in Figure 6. Because the channel characteristics are not a simple relation with discharge, the three relations only give some idea of the physical habitat ranges that may have occurred over time.

Observation 2. Change in the channel index with time as a habitat variable.

Figure 7 shows the change over time in the bed-material composition of the Little Round Valley reach of the Virgin River. The substrate index (the name used for the channel index when the size of the sediment is the index) was a visual classification based on particle size based on the modified Wentworth scale used by geologists. Note the loss of sand in the 222 days between the low and middle discharge measurements. The river is tending to return to a previous state as far as the composition of the substrate is concerned. Because the substrate suitability is the same (1.0) for all values of the substrate index and for all fish and life stages, the impact of the change in the substrate is important only for the hydraulic simulations. The change is important in the hydraulic calculations because a change from a sandbed stream to a cobble stream could result in a doubling of the roughness used in the water surface elevation calculations. 


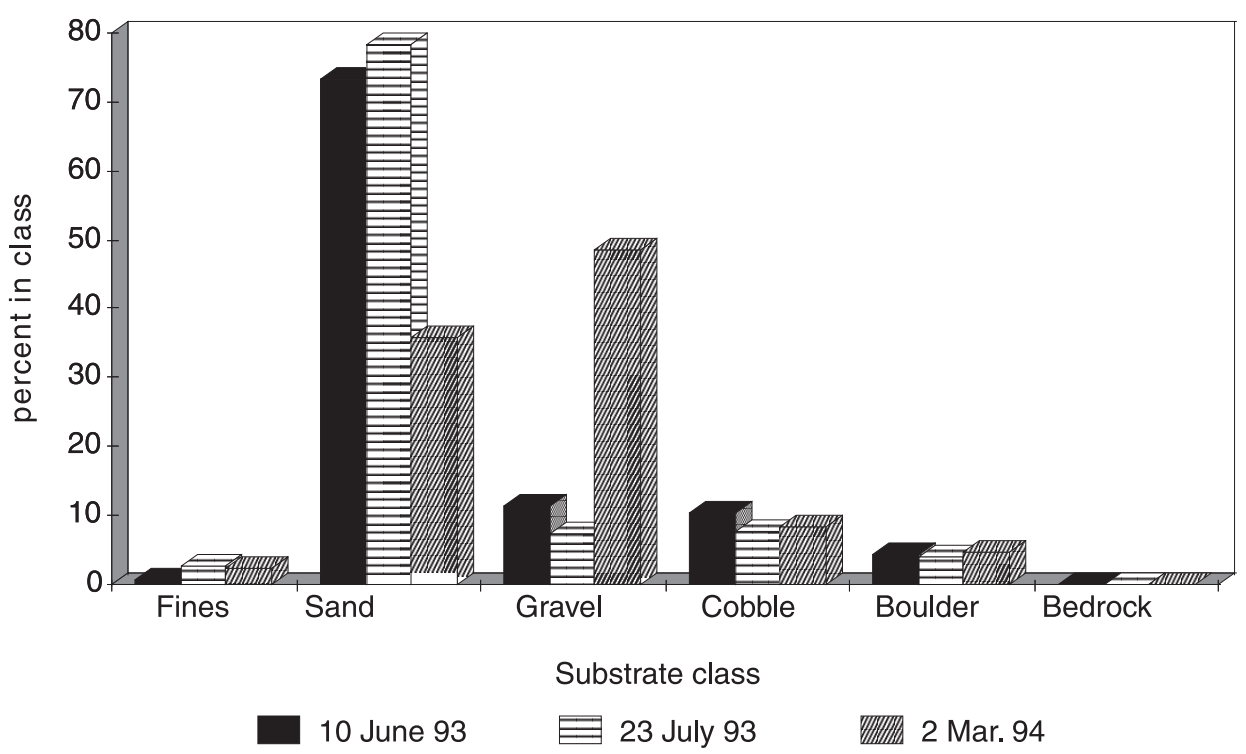

Fig. 7. - The change in the bed-material composition of the Little Round Valley Reach of the Virgin River as indicated by the observed substrate index.

\section{ANIMAS RIVER CASE STUDY}

The Animas River is located in the San Juan Mountains and Colorado plateau of southwestern Colorado and northwestern New Mexico and joins the San Juan River at Farmington, New Mexico. The native trout in the Animas Basin are cutthroat trout. Few native trout remain and the trout found in the upper watershed are brook trout with rainbow and brown trout in the lower river. There is considerable metals contamination in the upper basin near Silverton but a brook trout fishery does exists in the Animas River from just above Howardsville to where the Animas joins Cement Creek in Silverton (Milhous, 1999). The Upper
Animas River watershed is in San Juan County, Colorado and is located in the San Juan Mountains. The lower river is in the Colorado Plateau country. The winters are cold with considerable snowfall and little snowmelt in the mountains in the upper part of the basin. The lower basin has less snow but the winters are still cold. The streamflows during the winter are low and reasonably stable.

Observation 3. The simulation of time series linking high and low streamflows and habitat conditions

The high flow condition in the Animas River considered in this paper is spring runoff; the low flow streamflow conditions are winter 


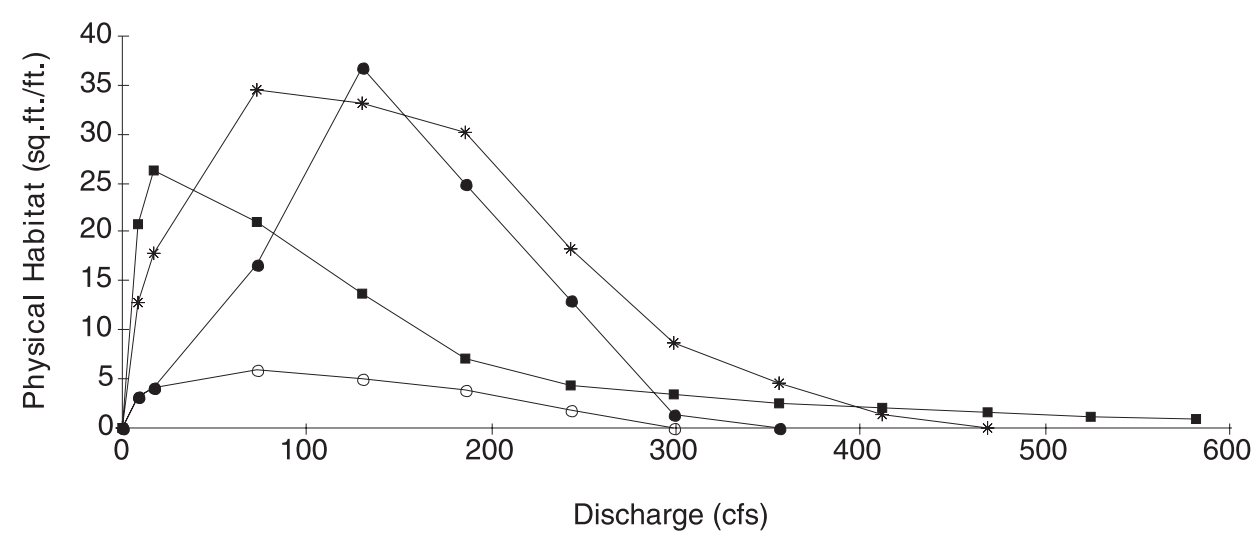

$\rightarrow$ Adult

- Winter

$\rightarrow$ win w/ shelters

Fig. 8. - Physical habitat as a function of discharge for the Animas River at Howardsville. The HABVD program in PHABSIM was used to generate the relations. The win w/ shelters (winter habitat with velocity shelters) relation includes the size of the surface armour in the generation of the physical habitat. (100 cfs $=2.83 \mathrm{cms}$ and $10 \mathrm{sq} . \mathrm{ft} . / \mathrm{ft} .=3.048 \mathrm{sq} . \mathrm{m} . / \mathrm{m}$.)

streamflow. The physical habitat as a function of discharge relations in the Animas River at Howardsville for trout and benthic invertebrates are presented in Figure 8. This analysis is based on discharge measurements at the gage and calculated using the HABVD program in PHABSIM (Milhous et al., 1989). The winter physical habitat (label 'winter' on Figure 8 ) for trout is much less than the habitat the rest of the year because the velocity criteria for the physical habitat requires a lower velocity for the same level of suitability. The winter habitat criteria used in the calculation of the winter habitat relation in Figure 8 were developed for a study of the Gunnison River to the north of the Animas River watershed reported by Nehring and Miller (1987). The other trout criteria were modified for the Animas River study from criteria developed for the Salmon River in New York (Culp and Homa, 1991). The relation in Figure 8 labeled 'win w/ shelters' (an alternative winter habitat relation) will be explained in the section on winter habitat.

There are two periods causing habitat stress on trout because physical habitat conditions are not optimal; one of these is the high flow period during spring runoff and the second is the winter period. Both of these will be discussed in the sections below. Water quality can be limiting and a time series model of the water quality limiting factors will be presented in a section as part of the fourth observation.

\section{Spring Snow-melt Habitat}

The relation for Animas River trout becomes zero at $702 \mathrm{cfs}(19.9 \mathrm{cms})$. The model used to develop the rela- 


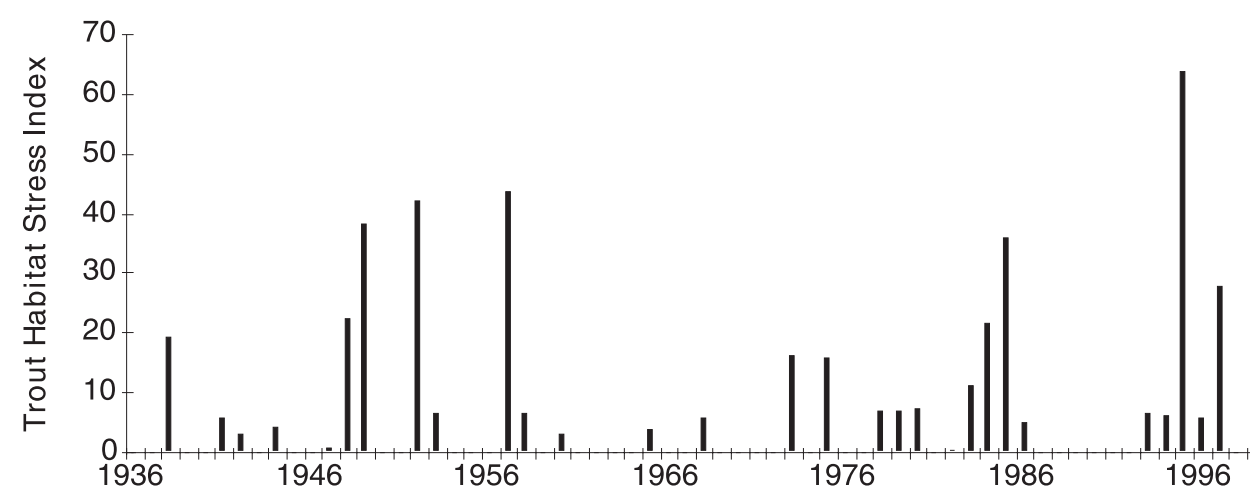

Water Year

Fig. 9. - Annual spring runoff trout habitat stress index for the Animas River at Howardsville. A positive value of the index means the velocities exceed the upper limit of the velocity criteria.

tion does not adequately account for velocity hiding places in the stream channel. The trout habitat stress index in Figure 9 is intended to show the years that may limit trout populations because of periods of adverse velocity habitat. The equation used to calculate a Trout Habitat Fish Stress Index (THSI) is THSI $=\Sigma((Q-702.0) /$ $100)$ and the summation is over a water year. Because the critical discharge is $702 \mathrm{cfs}$ (below which the habitat stress is zero) the summation is effectively over the spring runoff period. The assumption is that the velocities will inhibit fish growth and survival during the spring runoff period if the THSI is larger than zero. Additional details about the trout habitat stress index are presented in Milhous (1999).

\section{Winter Habitat Analysis}

The winter streamflows are small relative to the annual discharge. The river provides habitat for trout in reaches where the water quality does not limit the fish populations. Analysis in a previous paper (Milhous, 2002) showed that winter habitat conditions are limiting for trout populations if velocities and depths are the only habitat variables considered but if the size of the substrate is added to the physical habitat then there is winter habitat for certain sizes of fish. Analysis of the substrate sizes in the upper river shows that the range of sizes of the surface rocks (armour) may provide reasonable winter habitat for trout but that the expected trout species would be the smaller species (for example brook trout). Brook trout are found in the upper river.

The distribution of the sizes of the armour at four locations in the reach of river that we are interested in is shown in Figure 10. The reach upstream of Howardsville is relatively flat and the reach downstream relatively steep. The site used in the sim- 


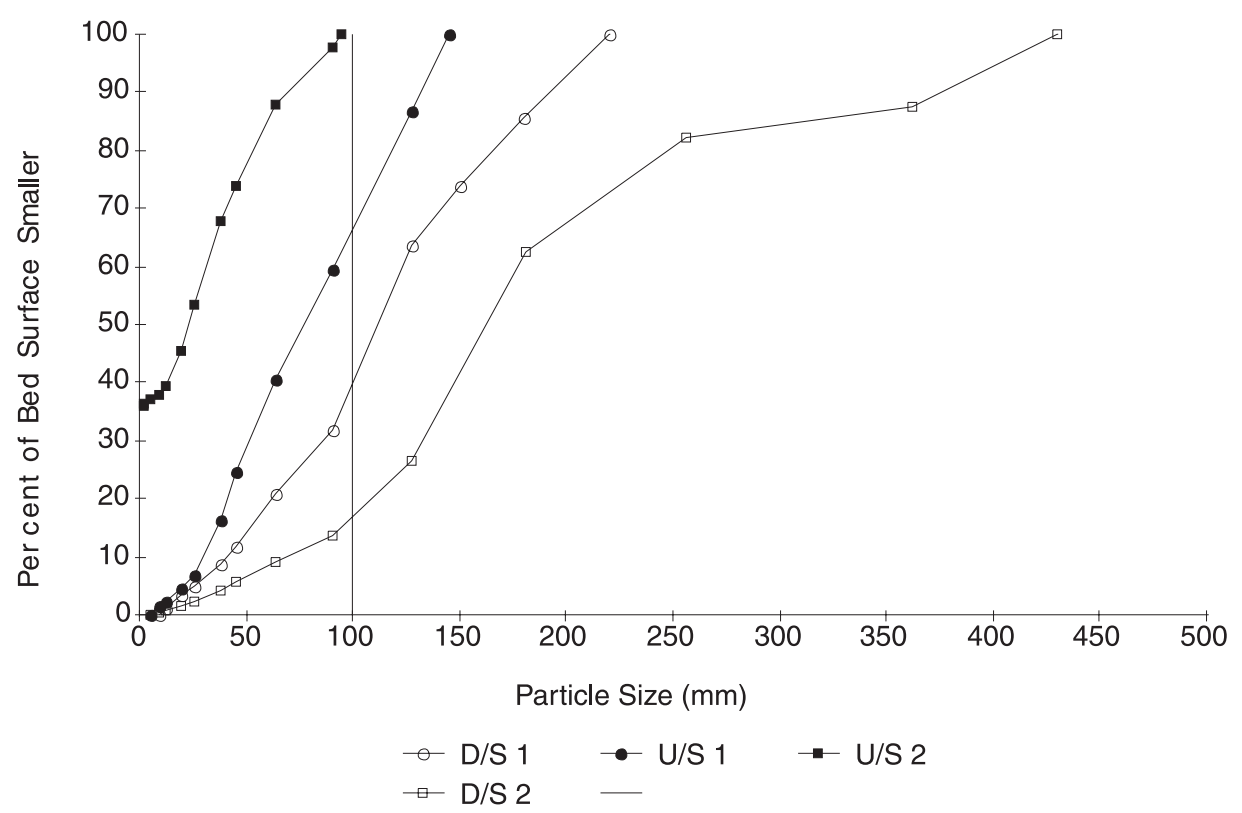

Fig. 10. - Surface (armour) bed-material of the Animas River near Howardsville. Two sample locations are downstream (D/S) of Howardsville, and two are upstream (U/S).

ulation of the physical habitat is probably reasonably representative of the reach as a whole. An assumption at this point is that the particle sizes are a good way of estimating the size of the hiding places in the surface. For that reason an average of the percentage of the surface armour is used as a weight for the percentage of the surface with hiding from winter high' velocities. The size needed was assumed to be at least $10 \mathrm{~cm}$ (based on the HEP criteria, Raleigh, 1982). The percentage of each sample less then $10 \mathrm{~cm}$ was 39.8 , $66.2,100.0$, and 10.5 for an average of $54.1 \%$ for the reach. This means that $45.9 \%$ of the reach has adequate substrate and the reach suitability weight for the substrate is 0.459 .
The two sets of winter habitat versus discharge relations are shown in Figure 8 ('winter' and 'win w/ shelters'). The 'winter' relation is based on the fish not having places to hide from the velocities in the stream. The velocity hiding relation assumes that fish can find a place to hide if the velocities are less than $4.1 \mathrm{cfs}$ $(0.116 \mathrm{cms})$ and the habitat is weighted 1.0 for velocities less than $4.0 \mathrm{cfs}(0.113 \mathrm{cms})$. The substrate weight was 0.459 obtained from the armour size distribution shown in Figure 10 and discussed above.

A winter habitat time series analysis was done using winter streamflows of the minimum average 10-day discharge in the winter which was assumed to be between 1 December 


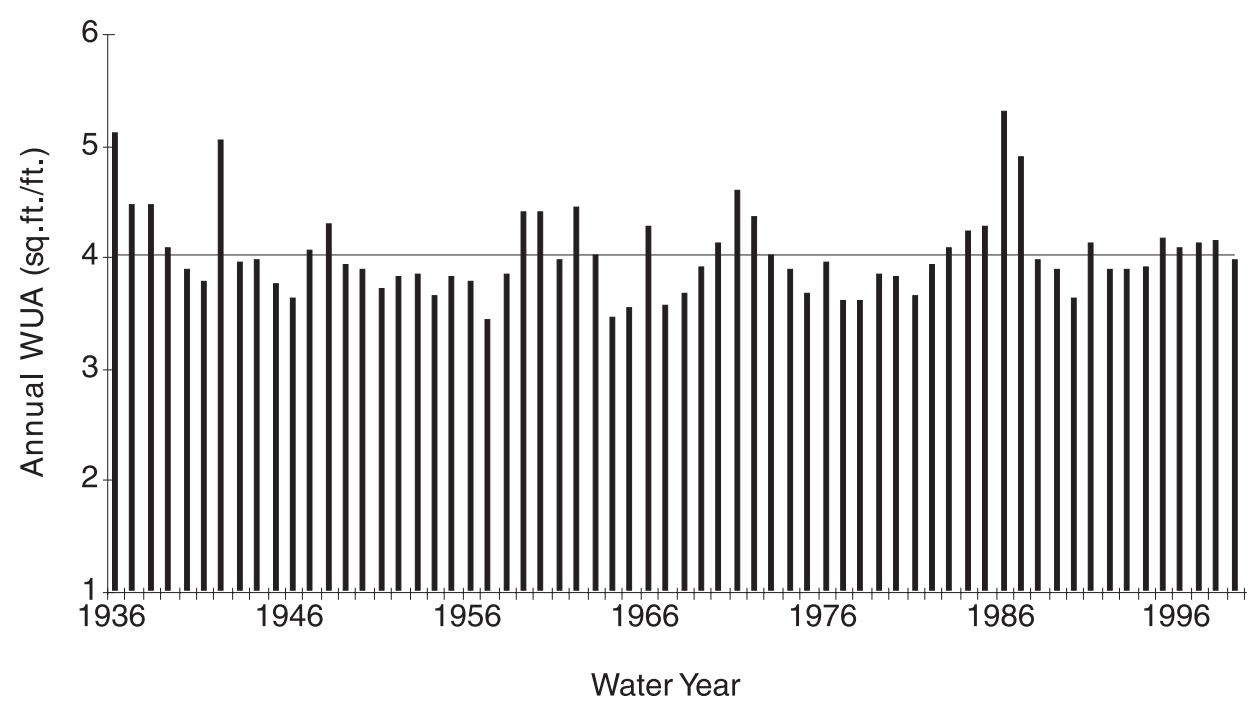

Fig. 11. - Annual winter habitat in the Animas River at Howardsville, Colorado. The habitat was calculated using the Physical Habitat Simulation System. (4 sq. ft./ft. $=1.22$ sq. m. $/ \mathrm{m}$.)

and 28 February of each water year. The velocity hiding relation from Figure 8 was used as the physical habitat function needed to transform the streamflows to the annual winter habitat time series presented in Figure 11. There is not much variation in the winter habitat from year to year.

Two trout species (brown and brook) spawn in the fall and the eggs incubate during the winter. The fall stream flows are higher than in the winter which means there can be a loss of eggs because of de-watering of redds as has been observed in the Gunnison River (Nehring and Miller, 1987). An index to the spawning habitat loss was calculated using a discharge versus width function based on the USGS discharge measurement summaries. The spawning habitat loss is the percent width reduction calculated as the difference in the width during the spawning period in October and the minimum width between 1 December to 28 February period (or 0 if there is not a reduction in width) divided by the width in October. The October spawning width is assumed to be the width at the average discharge for October. The minimum width between 1 December 28 February is assumed to be the minimum width that incubates during the winter. The spawning habitat loss for each water year is shown in Figure 12. The spawning habitat loss is sometimes significant (between 20 and $30 \%$ ) and other times maybe not as significant (5 to $10 \%$ ). The working assumption behind the index is that redds are uniformly distributed across the width. This is probably not true and the index will underestimate 


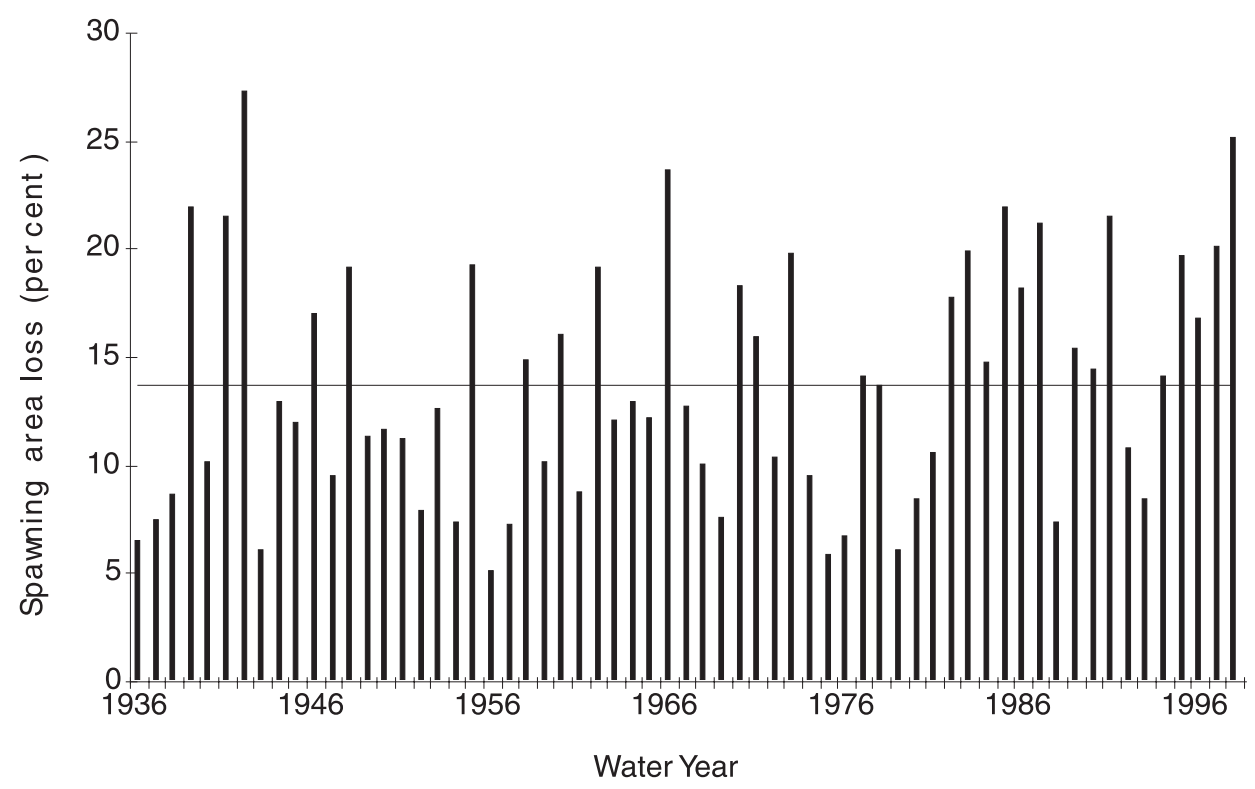

Fig. 12. - Percent of fall spawning area lost by de-watering between time of spawning and the time of emergence of the fry from the gravels. Calculated using streamflow and cross section data for the Animas River at Howardsville

the loss if the redds are near the edge in October and overestimate the loss if the redds are in the channel bottom. For the upper Animas River the loss is probably underestimated.

The fry for fall spawning fish will emerge in the spring when the velocities may not be optimal. In the Animas River the fall spawning fish are brown and brook trout. The assumption is made that the fry habitat of importance is between 16 April and 15 July. It is also assumed the discharge to consider in calculating the fry habitat for each year is the maximum average discharge for a seven day period between 16 April and 15 July. The simulated annual habitat available to the fry of fall spawning fish is given in Figure 13.

The fry for spring spawning fish will emerge in the summer when the velocities may be closer to optimal (compared to fall spawning fish). In the Animas River the spring spawning fish are rainbow and cutthroat trout. The assumption is made that the fry habitat of importance is between 1 July and 31 August. It is also assumed the discharge to consider in calculating the fry habitat for each year is the maximum average discharge for a seven day period between 1 July and 31 August. The annual fry habitat for spring spawning fish is shown in Figure 14. 


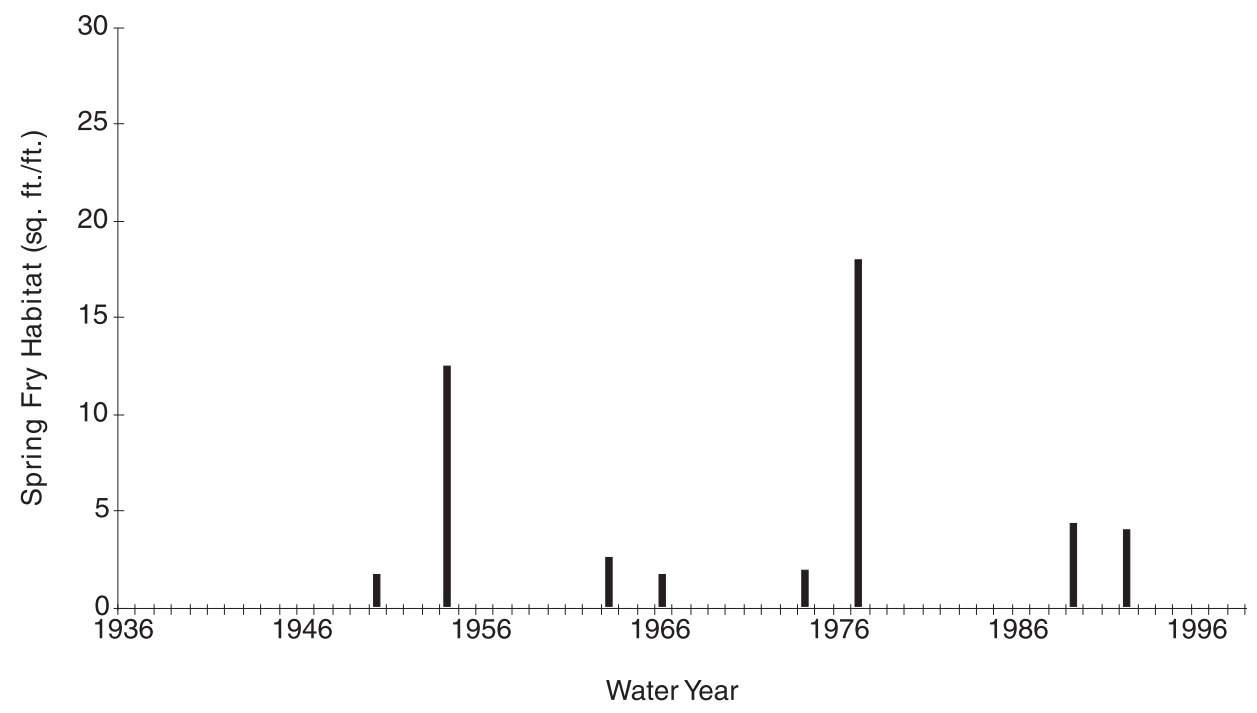

Figure 13. - Annual spring fry habitat available based on data for the Animas River at Howardsville. Spring fry habitat is the habitat available to trout fry emerging after incubation in the winter (fall spawning). (10 sq. ft./ft. $=3.048$ sq. $\mathrm{m} . / \mathrm{m}$.)

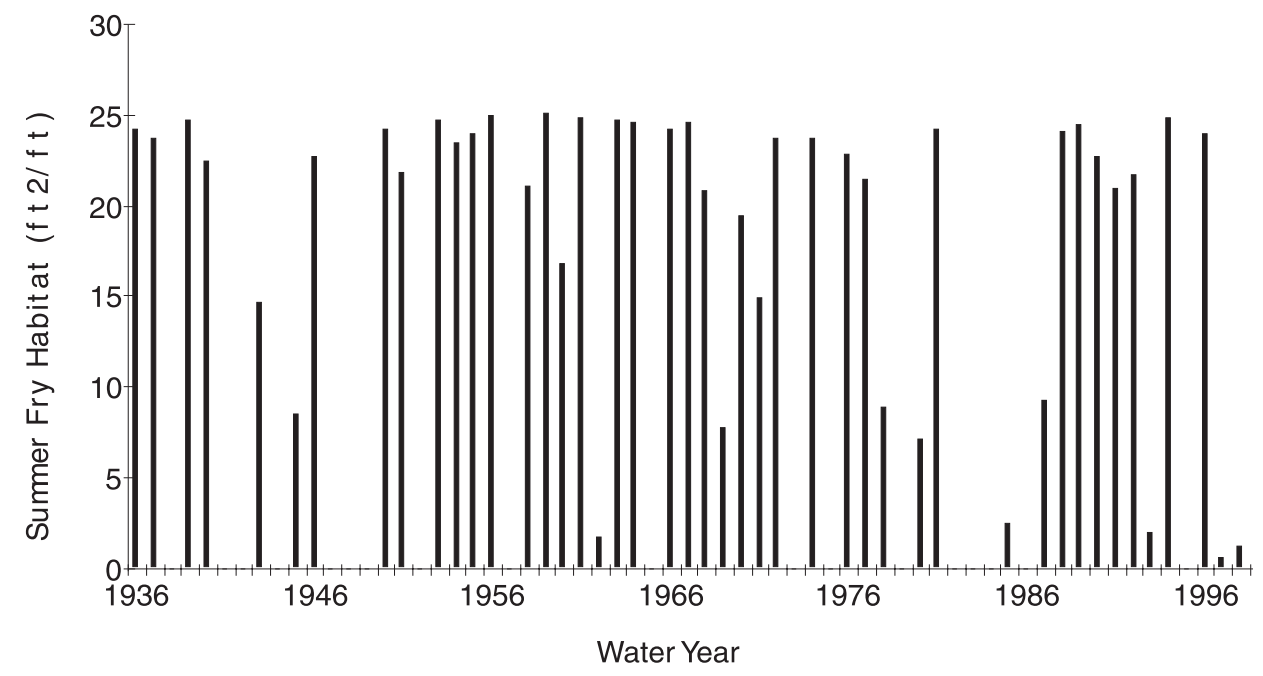

Fig. 14. - Annual summer fry habitat available based on data for the Animas River at Howardsville. Summer fry habitat is the habitat available to trout fry emerging after incubation in during the spring and early summer. (10 sq. ft./ft. $=3.048 \mathrm{sq} . \mathrm{m} . / \mathrm{m}$.) 
From the winter habitat time series analysis, an observation is that the hydraulic and hydrologic environment favors spring spawning fish. This is especially true when we consider the fry habitat conditions shown in Figures 13 and 14. From the trout habitat stress analysis it was learned there are spring conditions that may limit the numbers of trout found in the upper Animas River because there are years with a high stress index. The years with a high stress index are expected to limit the numbers of fish during a high stress year because the physical habitat available is small. If the habitat stress index is lower in following years the fish populations can recover.

Observation 4. Annual time series of habitat suitability considering metals transport in the river.

Annual variation of metals habitat suitability could be part of an analysis of the suitability of a river for trout if the metals concentrations are considered to be high. An approach to a time series of trout habitat suitability is presented below. The work is preliminary and will change with further investigation. The present objective is to show that metals impacted habitat time series analysis can (an probably should) be done when metals concentrations are high.

The variation of the metals concentrations can have a significant impact on the actual ability of aquatic animals to use the physical habitat. The variation of the concentration of zinc in the Animas River below Silverton is presented in Figure 15. The vertical lines represent boundaries between different levels of movement of the bed-material. The left most vertical line (at $279 \mathrm{cfs}, \quad(7.9 \mathrm{cms})$ with a dimensionless shear stress of 0.009 ) divides a very stable streambed from a streambed with a rather small amount of movement. At $602 \mathrm{cfs}$ $(17.0 \mathrm{cms}$, a dimensionless shear stress of 0.021 ) the relatively stable streambed becomes a bed with increasingly significant movement. At $958 \mathrm{cfs}(27.1 \mathrm{cms}$, a dimensionless shear stress of 0.035) the streambed has a high portion of the bed-surface in motion. At $1680 \mathrm{cfs}(47.6 \mathrm{cms}$, a dimensionless shear stress of 0.084 ) about $90 \%$ of the stream-bed is in motion and there is general bed material transport.

In Figure 15 it would seem that for discharges less than $279 \mathrm{cfs}(7.9 \mathrm{cms})$, the zinc concentration is not related to discharge. In Figure 16 the evidence is that the zinc concentrations following spring runoff are instead related to the time following the major fraction of the runoff.

The model used to simulate daily zinc concentrations has two components (see Figures 15 and 16). The first component is when the discharge is larger than $270 \mathrm{cfs}(7.6 \mathrm{cms})$. In the first component, the zinc concentration is $300 \mu \mathrm{g} / \mathrm{l}$ except for the first four days following the winter low flows. For the first four days following winter which also exceed $550 \mathrm{cfs}$, the concentration is $500 \mu \mathrm{g} / \mathrm{l}$ because the substrate is moved allowing metals to be flushed from the substrate (see 


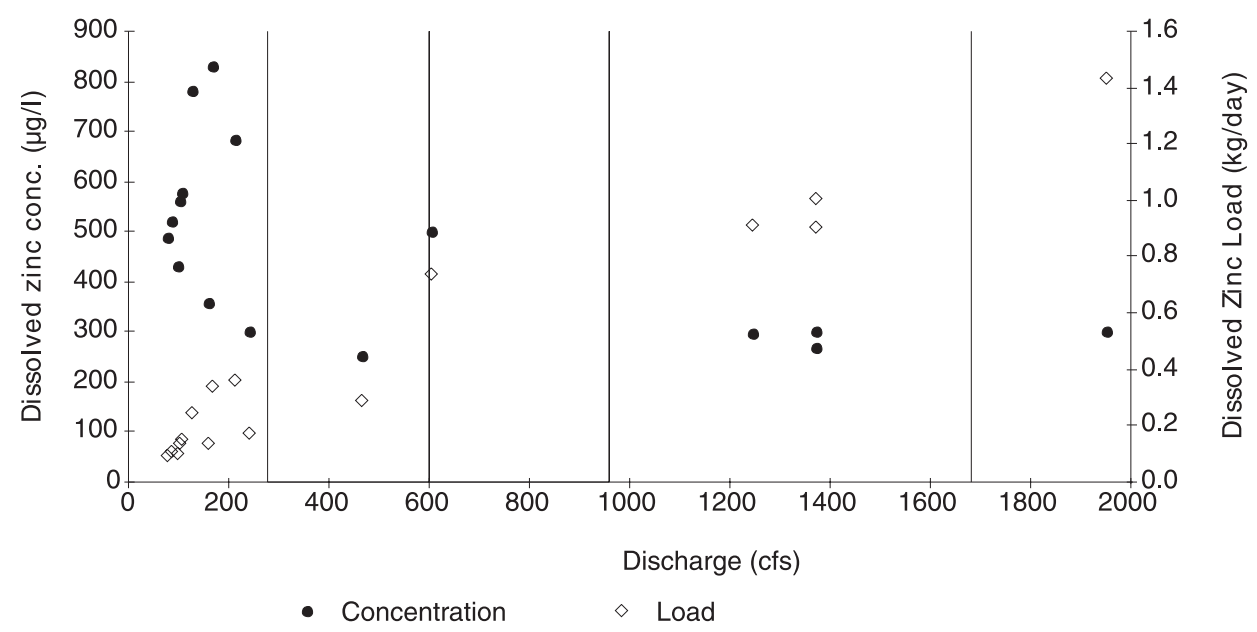

Fig. 15. - Discharge versus dissolved zinc concentrations for the Animas River below Silverton. The vertical lines divided the discharges into 'cells' of different bed-material movement capability of the river. $(100 \mathrm{cfs}=2.83 \mathrm{cms})$

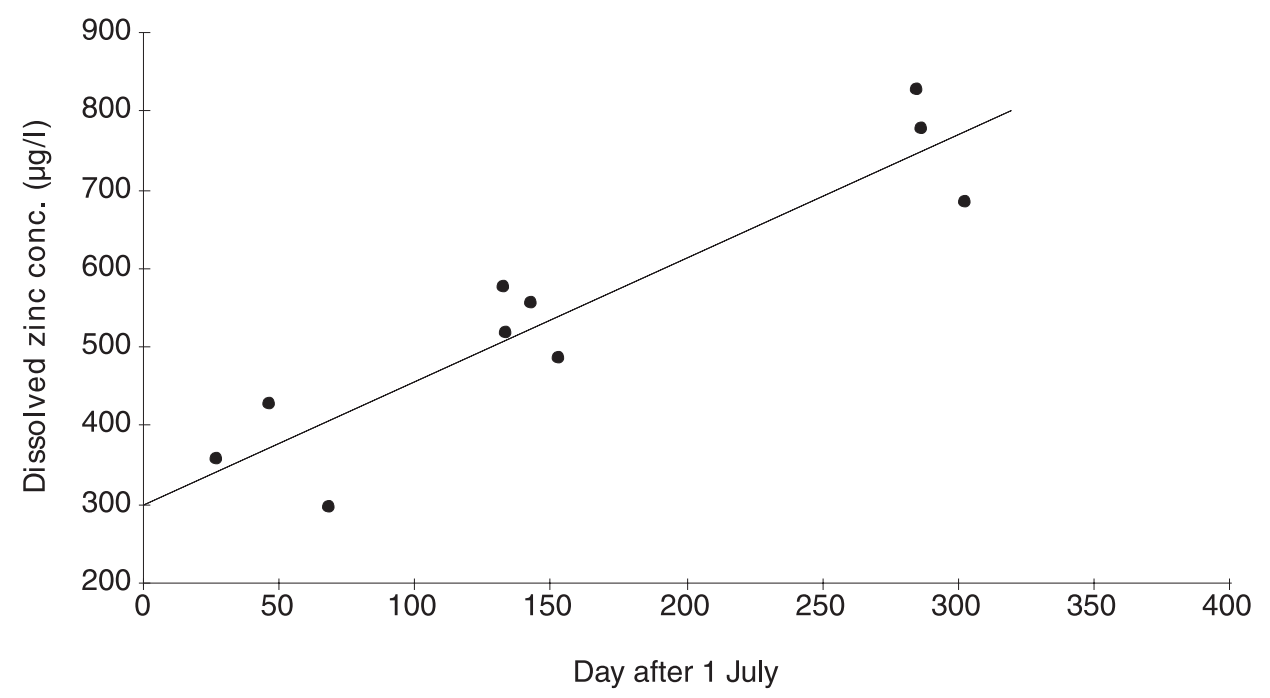

Fig. 16. - The relation between the number of days after the spring runoff ( 1 July) and the zinc concentration.

below). The second component is for discharges less than $270 \mathrm{cfs}$ $(7.6 \mathrm{cms})$. For a discharge less than
$270 \mathrm{cfs}(7.6 \mathrm{cms})$ the relation used is zinc concentration (in $\mu \mathrm{g} / \mathrm{l})=300.0+$ $1.5625^{*}$ day, where day is the num- 


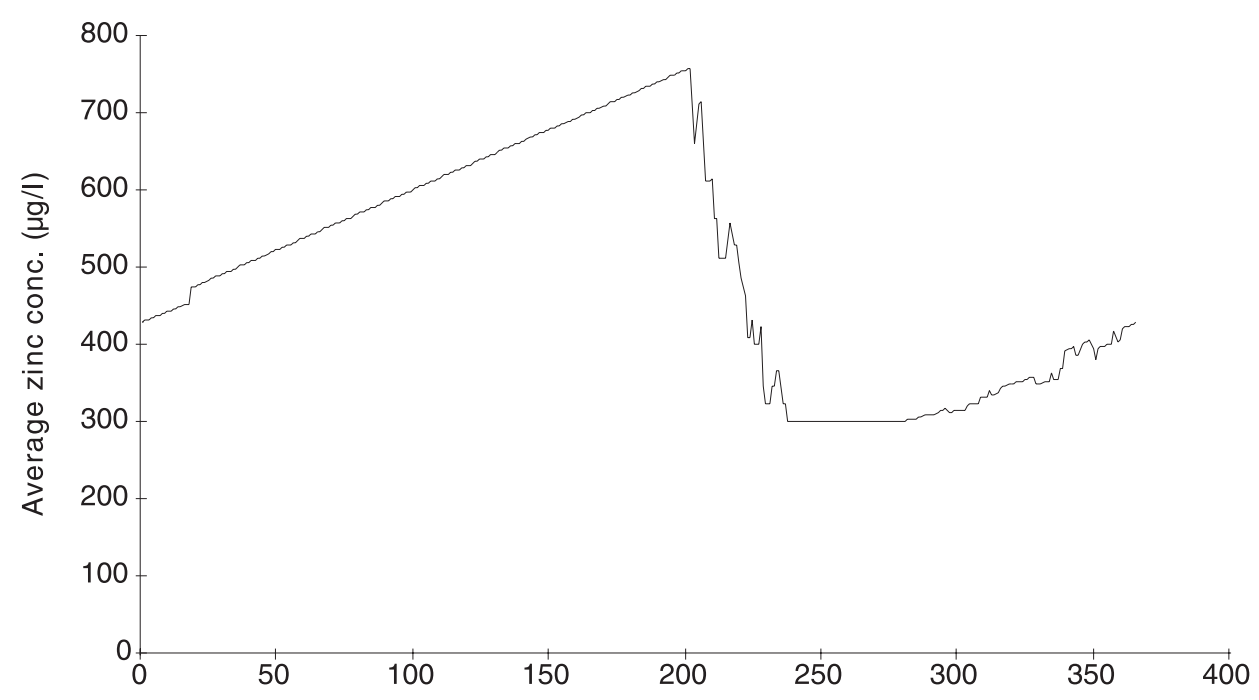

Day in water year

Fig. 17. - The average daily zinc concentration simulated for the Animas River below Silverton.

ber of days after the end of June. The reason for a higher concentration of zinc the first four days when the discharge exceeds $550 \mathrm{cfs}(15.6 \mathrm{cms})$ following winter is that $550 \mathrm{cfs}$ $(15.6 \mathrm{cms})$ is the discharge at which the streambed is starting to be moved by the flowing water. This means the streambed is flushed of stored zinc. An alternative explanation is that at a discharge of about $550 \mathrm{cfs}(15.6 \mathrm{cms})$, the watershed is flushed of water that has had a relatively long time in contact with the rocks. The average annual zinc concentrations generated using this model are presented in Figure 17.

A habitat suitability function for cutthrout trout is presented in Figure 18. The cutthroat suitability curve was developed for zinc from three sources. The first is a paper by
Woodward et al (1997) that reports cutthroat trout will avoid, if they can, waters with a concentration over 28 $\mu \mathrm{g} / \mathrm{l}$ in the Cœur d'Alene basin in Idaho. The assumption in Figure 18 is that the chronic limit for cutthroat was the same as for rainbow trout and information in Besser and Leib (1999) can be used; the acute limit is from Besser and Leib (1999). Woodward et al (1997) indicate that avoidance of metals contaminated habitats by cutthroat trout may cause a reduction in fish populations. In other words, trout populations can be reduced when zinc concentrations are well below toxic concentrations.

The zinc concentrations in Figure 17 were combined with the suitability relation in Figure 18 to give a time series for zinc habitat suitability presented in Figure 19. The annual 


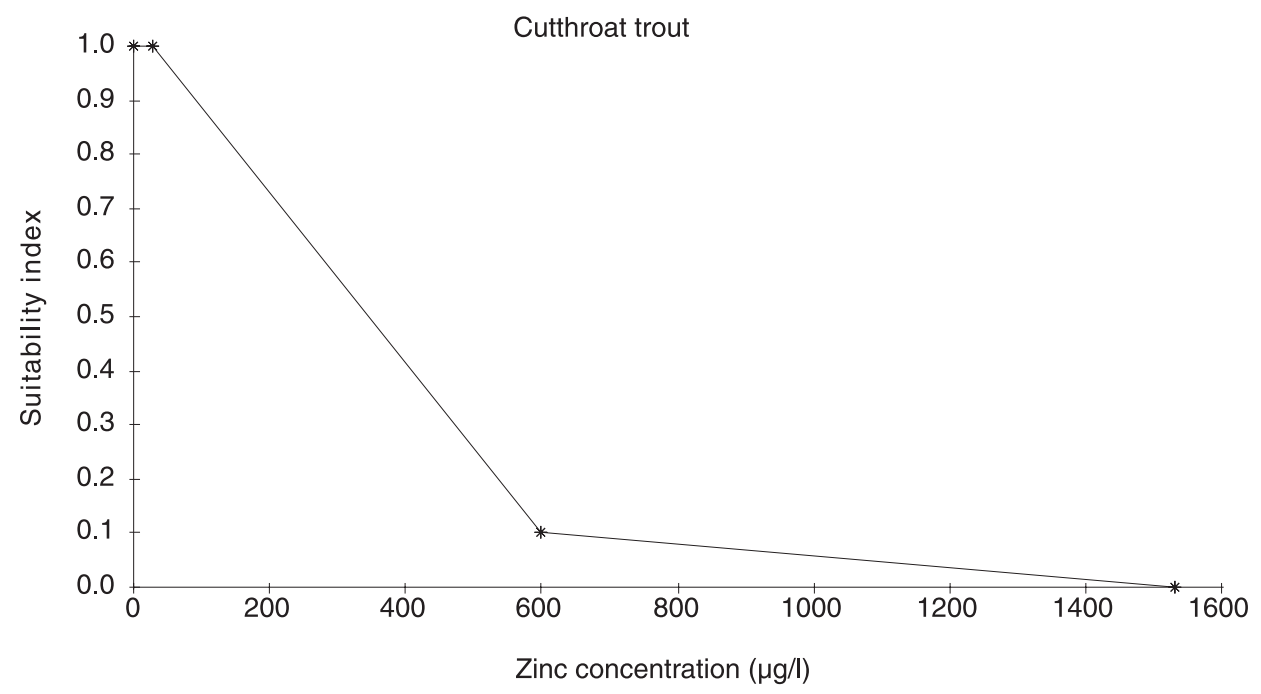

Fig. 18. - Cutthroat trout habitat suitability function for zinc concentrations.

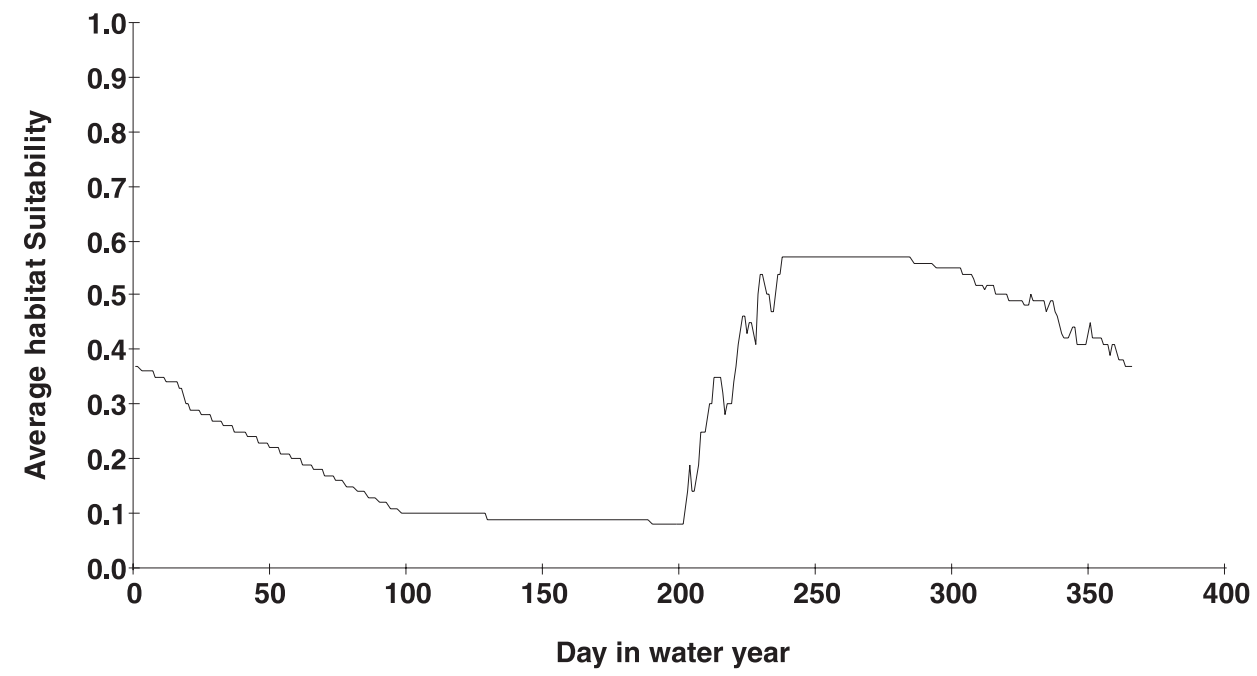

Fig. 19. - Daily average cutthroat trout habitat suitability calculated from simulated zinc concentrations in the Animas River below Silverton.

values of the zinc suitability are presented in Figure 20 for both cutthroat and brook trout (a similar relation was developed for brook trout using judg- ment and information in Besser and Leib (1999)). Rainbow trout would have similar values to cutthroat trout and brown trout similar values to 


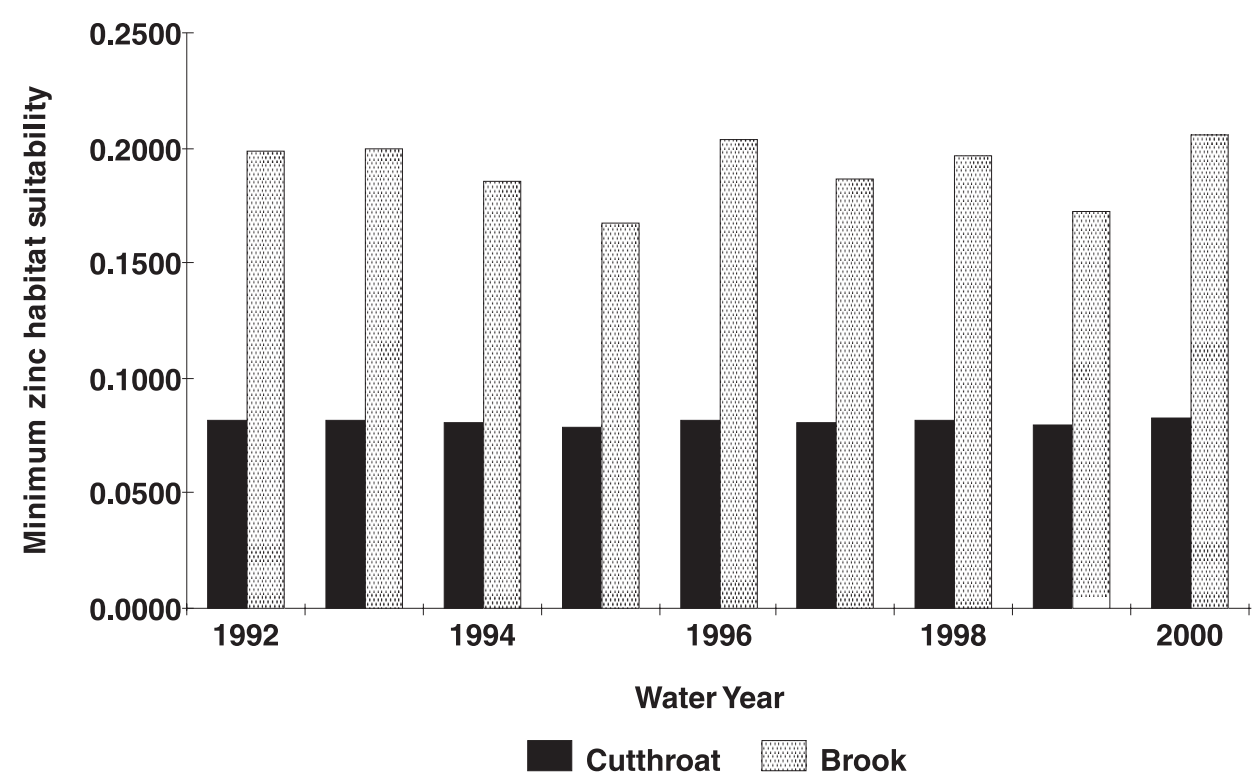

Fig. 20. - Annual zinc habitat suitability for cutthroat and brook trout in the Animas River below Silverton. The annual habitat is the minimum of the daily habitat suitability values in a water year.

brook trout. The minimum daily value during a water year of the suitability was used as the annual values of the suitability. This minimum habitat suitability occurred between 23 April and 12 May for the 9 years of record used in the analysis.

The analysis demonstrates that annual habitat suitability indices related to zinc concentrations can be calculated. The most difficult part is the development of a model to calculate the daily zinc concentrations.

\section{DISCUSSION}

The first observation based on the Virgin River channel change analysis is that it is important to keep the three sets of data as individual data sets. There is also a related observation. There was significant difference in the high and low time series in Figure 6 . The problem is that the differences of the high and low compared to the middle data set relation may be a result of the habitat calculated for a discharge of $1000 \mathrm{cfs}$. This suspected upturn in the calculated habitat indicates there might be problems with the model being used (in this case PHABSIM) when a transitional channel is being analyzed.

The substrate changed significantly between the three data sets. The second observation is that the channel index is not fixed (the usual 
assumption) in a river with a moveable-bed and the changes can be significant and important to an understanding of the aquatic system. In the paragraph above a statement about a transitional channel' was made. It is possible that the middle discharge data set is the stable data set. In Figure 3 the middle discharge profile is below the low and high discharge data sets; also, there is more gravel in the channel for the middle discharge data set (Figure 7) and the river is mostly sand-bed for the high and low data sets. It is probable that a sand wave was deposited in the channel and passed through the channel during times of the high and low discharge measurements but was gone by the time of the middle discharge measurement. A sand wave is probable in years with a high Sediment Transport Capacity Index (Figure 5) but as a transitional feature. A moveable bed model may be needed to resolve questions about both the increases in habitat at $1000 \mathrm{cfs}$ for the low and middle discharge data sets and the impact of sand waves on the habitat.

The Animas River has a wide range of streamflows and considerable metals toxicity. Both winter and spring discharges may limit trout populations along with metals toxicity. The third observation is that habitat time series analysis should be done with a model that specifically links the physical habitat relations and the streamflows, and quantifies the limiting factor(s). In the case of winter flows the model is a physical habitat model that includes armour size of the streambed as a habitat factor. For high streamflows (spring runoff), the model is a representation of the time and magnitude the high flows are larger than the highest discharge with acceptable velocities. The high discharge model suggests an improved approach to habitat criteria is probably needed.

The fourth observation is that a time series of habitat suitability considering metals toxicity can be calculated. The third and fourth observations show that the hydraulic and streamflow conditions may favor different fish than the metals toxicity conditions. In the Animas River the hydraulic and streamflow conditions favor spring spawning fish. The habitat suitability for zinc concentrations would be better for brook and brown trout (fall spawning fish) than for cutthroat and rainbow trout (spring spawning fish).

The Animas River case study illustrates a concern about habitat analysis. The criteria developed for use in PHABSIM most often is intended to show the physical conditions desired by an aquatic animal. This was the case for the relations in Figure 11 except for the winter habitat with velocity shelters relation. The 'win w/ shelters' relation was developed to show that for winter conditions when optimal habitat was not available (or very small) there could still be survival habitat. The same type (survival) analysis could have been done for high flows but instead a habitat stress index analysis was done - the as- 
sumption was that the some of the fish would probably survive but with reduced numbers if the high flow habitat stress index was large (Figure 9). Taken together, the idea is that normal PHABSIM analysis may give good results for most of the year but it would be a good idea to consider how fish (and other aquatic animals) survive in adverse flow conditions when the habitat conditions approach low values. The cutthroat trout zinc suitability relation illustrates a similar idea. Cutthroat trout will avoid, if they can, waters with a zinc concentration over $28 \mu \mathrm{g} / \mathrm{l}$. The toxic limits are much higher. What happens if the concentration is over $28 \mu \mathrm{g} / \mathrm{l}$ ? Is this a survival situation? It is possible that in environmental flow analysis, both desirable and survival flow analysis should be done. In other words, when a time series of habitat is done using a physical habitat versus discharge relation and the habitat is zero, the analysis should then include some information on the ability of the aquatic animal to survive zero desirable habitat. It is possible the length of time the zero desirable habitat, but with survival habitat greater than zero, occurs will play a crucial role in the environmental flow analysis.

The examples presented in this paper illustrate how to transform streamflows and habitat factors to time series of biologically relevant factors using the measured streamflows. One application of the concepts is to use pre-project streamflows for one time series of biologically relevant factors, do the same for post-project streamflows and compare the results to obtain some idea of the impact of a project on the biological resources.

\section{REFERENCES}

Besser, J.M. and K.J. Leib. 1999. Modeling Frequency of Occurrence of Toxic Concentrations of Zinc and Copper in the Upper Animas River. Pages 75-81 in D.W. Morganwalp and H.T. Buxton, editors. U.S. Geological Survey Toxic Substances Hydrology Program-Proceedings of the Technical Meeting, Charleston, South Carolina, March 812. Volume 1 of 3 - Contamination from Hard-Rock Mining. USGS WaterResources Investigations Report 994018A. U.S. Geological Survey, Reston, Virginia USA.

Culp, T.R. and J. Homa, Jr. 1991. Fish and Macroinvertebrate Habitat Suitability Index Curves. Report to Niagara Mohawk Power Corporation. Ichthyological Associates. Lansing, New York.

Karr, J.R. 1991. Biological Integrity: A Long-Neglected Aspect of Water Resources Management. Ecological Applications, 1(1): 66-84.

Meyer, K.A. and J.S. Griffith. 1997. Effects of Cobble-Boulder Substrate on Winter Residency of Juvenile Rainbow Trout. North American Journal of Fisheries Management, 17: 77-84.

Milhous, R.T. 1995. Changes in sediment transport capacity in the Lower Gunnison River, Colorado, USA. Pages 275280 in G. Petts, editor. Man's Influence on Freshwater Ecosystems and Water Use. IAHS Publication 230.

Milhous, R.T. 1999. Aquatic Physical Habitat and Hydrology in Abandoned Mine Land Studies. Pages 47-54 in D.W. Morganwalp and H.T. Buxton, editors. U.S. Geological Survey Toxic Substances Hydrology Program - Proceedings of the Technical Meeting, 
Charleston, South Carolina, March 812. Volume 1 of 3 - Contamination from Hard-Rock Mining. USGS WaterResources Investigations Report 994018A.

Milhous, R.T. 2002. On Trout Winter Habitat in the Animas Basin. Pages 191202 in J.A. Ramirez, editor, Proceedings of the Twenty Second Annual American Geophysical Union HYDROLOGY DAYS. Hydrology Days Publications. Colorado State University, Fort Collins, Colorado USA..

Milhous, R.T., M.A. Updike, and D.M. Schneider. 1989. Physical Habitat Simulation System Reference ManualVersion II. Instream Flow Information Paper No. 26. U.S. Fish and Wildlife Service. Biological Report 89(16). Washington, DC USA

Milhous, R.T., J.M. Bartholow, M.A. Updike, and A.R. Moos 1990. Reference Manual for Generation and Analysis of Habitat Time Series Versionll. Instream Flow Information Paper No. 27. U.S. Fish and Wildlife Service. Biological Report 90(16). Washington, DC USA.

Nehring, R. B. and D. D. Miller. 1987. The Influence of Spring Discharge Levels on Rainbow and Brown Trout Recruitment and Survival, Black Canyon of the Gunnison River, Colorado. In Proceedings of the Annual Conference of the Western Association of Fish and Wildlife Agencies, July 13-15,1987. Salt Lake City, Utah USA.

Raleigh, R.F. 1982. Habitat Suitability Index Models: Brook Trout. U.S. Fish and Wildlife Service. Report FWS/ OBS-82/10.24. Washington, DC USA

Raleigh, R.F, T. Hickman, R.C. Solomon, and P.C. Nelson. 1982. Habitat Suitability Index Models: Rainbow Trout. U.S. Fish and Wildlife Service. Report FWS/OBS-82/10.6. Washington, DC USA.

Raleigh, R.F., L.D. Zuckerman, and P.C. Nelson. 1986. Habitat Suitability Index Models: Brown Trout. U.S. Fish and Wildlife Service. Biological Report 82(10.124). Washington, DC USA.

Woodward, D.F., J.N. Goldstein, and A.M. Farag. 1997. Cutthroat Trout Avoidance of Metals and Conditions Characteristics of a Mining Waste Site: Cœur d'Alene River, Idaho. Transactions of the American Fisheries Society, 126: 699-706. 
